DOI 10.15407/mics2020.09.033

УДК 94(477.63)Голокост

\author{
Анна Медведовська, \\ кандидатка історичних наук, \\ Украӥнський інститут вивчення Голокосту «Ткума», \\ Дніпровський педагогічний коледж \\ КЗВО «"Дніпровська академія неперервної освіти” \\ Дніпропетровської обласної ради» \\ e-mail: medvedovskaya_an@ukr.net \\ https://orcid.org/0000-0002-7014-4929
}

\title{
ПАМ'ЯТЬ ПРО ГОЛОКОСТ У СИМВОЛІЧНОМУ ПРОСТОРІ ДНІПРА (ДНІПРОПЕТРОВСЬКА)
}

У статті на основі аналізу особливостей роману Юрія Винничука «Танто смерті» проаналізовано авторські наративні стратегії переосмислення на прикладі Львова сюжетів міської історії у 1930-1940-х роках, реконструкиї колективної і персональних пам'ятей містян. Проаналізований письменницький текст є суттєвим прикладом «вписування» Львова у пам'яттевий дискурс сучасної української літератури, а тому має два часові зрізи - довоєнний/воєнний (міжвоєнний період, роки Другої світової війни) і сучасний. Досліджувані подї̈ вивчаються як історія містян (зокрема взаємин дітей бійців Армії УНР, розстріляних 1921го під Базаром), які є носіями різних, часто конфліктних начіональних ідентичностей, виклику щцодо можсливостей реконструкиї пам'яті про «спільний» Львів в умовах військово-політичного конфлікту і радикального загострення міжнаціональних взаємин, а також як відновлення пам'яті про Янівський концентрачійний табір. Стверджується, що уявну та справжню поліфонію взаємин у передвоєнному Львові (як $і$ в інших містах Галичини), а також дитинство-юність героїв «історичної» частини роману Ю. Винничука руйнує вересень 1939 року. Подї Другої світової війни, описані на прикладі Львова, є важсливим компонентом міської пам'яті, а пережиті страждання героїв роману можна назвати одним із потужних детермінантних елементів національної ідентичності. У своєму романі Ю. Винничук вдається до отілеснення музики, інсиенізуючи текст роману як «танто», створюючи тим самим партитуру поліфонічності Львова з міста-перехрестя у місто-жертву з його мешканиями. На прикладі роману Ю. Винничука показано, що «львівська» пам'ять є маркером темпорального горизонту, зокрема комунікативна пам'ять передає історичний досвід міста у межах індивідуальних біографій протагоністів роману за допомогою живих спогадів, безпосереднього досвіду й усної оповіді. Запропоновано розглядати письменника як носія мнемонічного інформачійного ресурсу, того, хто накопичуе пам'ять про трагічні сторінки міської історії і ретранслюе до своїх сучасників. Аналіз роману Ю. Винничука «Танто смерті» пока- 
${ }^{1}$ Портнова, Т. (2017). Тема «закритого міста» 6 історії радянського Дніпропетровська 1950-80 рp. Retrieved from http://www. historians.in.ua/index.php/en/ doslidzhennya/2351-tetyanaportnova-tema-zakritogomista-v-istoriji-radyanskogodnipropetrovska-1950-80-khrokiv.

2 Портнов, А., \& Портнова, Т. (2014). Столица застоя? Брежневский миф Днепропетровска. Неприкосновенный запас, 5. Retrieved from https://magazines.gorky. media/nz/2014/5/stoliczazastoya-brezhnevskij-mifdnepropetrovska.html.

${ }^{3}$ Там же.

\footnotetext{
${ }^{4}$ Офіційна назва музею «Пам'ять єврейського народу та Голокост в Україні».
}

зує, щзо, по-перше, Львів є прикладом не так символічного, як иілком реального місия пам 'яті, $i$, по-друге, підтвердженням сучасної тези А. Ассман про місие пам'яті, щзо «освячене присутністю мертвих».

Ключові слова: пам'ять про Голокост, представлення теми Голокосту, міський простір, місие масових страт, меморіальний знак.

$\Pi$ ісля розпаду СРСР і особливо упродовж останніх десятиріч відбувається активний пошук нової ідентичності міста на Дніпрі. Він супроводжується перебиранням численних різноманітних образів і сюжетів історії міста, його попередніх досягнень і амбіцій.

За радянських часів (1959-1987 рр.) місто мало статус умовно-закритого ${ }^{1}$ через секретне виробництво бойових ракет на Південному машинобудівному заводі. Унаслідок особливі відносини 3 центральною владою, посилений ідеологічний контроль, краще забезпечення продовольчими товарами та інші привілеї надавали місту відчуття власної значущості, що зумовлювало побутування в неофіційному дискурсі таких його характеристик, як «столиця застою» ${ }^{2}$, «кузня кадрів», а також жарту про «дніпропетровський період історії Русі» та ін. У пострадянській реальності, як стверджують дослідники Андрій і Тетяна Портнови, «у принципово новій політико-ідеологічній ситуації локальна функція брежнєвського міфу зберігає своє значення» ${ }^{3}$.

Сучасна міська влада, усвідомлюючи ці претензії, намагається підкреслити та, можливо, відродити поширений колись концепт так званої столичності, просуваючи у своїх програмах і проєктах імідж міста як промислової, бізнесової, науково-технічної, космічної та навіть культурної столиці.

Ще однією характерною особливістю, яка до певної міри формує обличчя Дніпра, є відроджене й розвинене єврейське життя результат діяльності потужної єврейської релігійної і культурної громади. Її лідерам вдалося залучити інвестиції та пожертви від місцевих бізнесменів єврейського походження, побудувати низку закладів соціальної допомоги, освітніх установ, відновити синагогу та створити 2012 р. один із найбільших у світі громадських центрів - «Менору», будівля якого нині є невід’ємною частиною панорами міста, одним із його візуальних символів.

Того ж року було відкрито перший на той час в Україні музей Голокосту ${ }^{4}$, в експозиції якого висвітлено історії та долі євреїв не лише в регіоні, а в усій Україні та в європейському контексті, що підкреслює загальноукраїнський масштаб і значущість Голокосту.

Отже, невід'ємним елементом нової ідентичності Дніпра стала успішна єврейська громада. Голокост як один із сутнісних аспектів єврейської історії загалом і цього міста зокрема також відтворено в міському просторі.

Це дослідження має на меті продемонструвати ключові меморіальні трансформації, які відбувалися на місцях Голокосту у Дніпрі (Дніпропетровську) від кінця окупації до сьогодення, проаналізувати, якою мірою ці території стали місцями пам'яті про Голокост, описати механізми й особливості вбудовування цієї пам'яті до символічного простору міста, з'ясувати, хто є основним ініціатором та споживачем/адресатом меморіалізації Го- 
${ }^{5}$ Круглов, А. (2008). К вопросу о количестве евреев, уничтоженных эйнзатцгруппами в 1941-1943 гг. Голокост і сучаснiсmb, 1 (3), 39-64.

${ }^{6}$ Беркгоф, К. (2011). Жнива розпачу. Життя і смерть в Україні під нацистською владою. Київ: Критика.

${ }^{7}$ Круглов, А., Уманский, А., \& Щупак, И. (2016). Холокост в Украине. Рейхскомиссариат «Украина». Губернаторство «Транснистрия». Днипро: Укр. ин-т изучения Холокоста «Ткума», Лира ЛТД.

${ }^{8}$ Врадій, Є. А., Рибалка, В. Г., Стрільчук, М. В., \& Шаталов, Д. В. (2017). Голокост у Дніпропетровську. Дніпро: Український інститут вивчення Голокосту «Ткума», ЛIРА.

\footnotetext{
${ }^{9}$ Касьянов, Г. В. (2018). Past Continuous: Icторична політика 1980-х - 2000-х: Україна та сусіди. Київ: Laurus, Антропос-Логос-Фільм.

${ }^{10}$ Гайдай, О., та ін. (2018).

Політика і пам'ять. Дніпро Запоріжжя - Одеса-Харків. Від 1990-х до сьогодні. Львів: ФОП Шумилович.

${ }^{11}$ Там само, 129-130.

${ }^{12}$ Портнов, А. (2011). O трех памятниках жертвам Холокоста. Размышления к 9 мая. Retrieved from http://urokiistorii. ru/blogs/andrei-portnov/1547.
}

локосту, оцінити, наскільки ефективно пам'ять про екстермінацію євреїв відтворено в міському просторі, наскільки вона відповідає його сучасному образу.

\section{Історіографія питання}

Тема Голокосту у Дніпропетровську, так само як і проблема пам'яті про нього, рецепція в суспільній думці та представлення в меморіальному просторі досить скромно висвітлені в сучасній істоpioграфії. Маємо надзвичайно вузьке коло робіт, до яких можна звернутися для того, щоб точно встановити основні місця, де було вчинено Голокост, на мапі міста та хронологію подій. Певною мірою політику нацистів щодо євреїв в окупованому Дніпропетровську було висвітлено у працях деяких краєзнавців або істориківаматорів, а також професійних дослідників, як-от О. Круглов ${ }^{5}$, К. Беркгоф ${ }^{6}$, А. Уманський, I. Щупак ${ }^{7}$ та ін. Проте цілісним і поки що найбільш повним регіональним науковим дослідженням геноциду євреїв Дніпропетровська є монографія колективу авторів Українського інституту вивчення Голокосту «Ткума» «Голокост у Дніпропетровську» ${ }^{8}$. Ця праця грунтується на широкій джерельній базі, яка охоплює архівні матеріали Державного архіву Дніпропетровської області (ДАДО), значну кількість наративних джерел, зокрема щоденники містян, які описували повсякдення окупації, матеріали усної історії - спогади очевидців та свідчення тих, хто вижив. Спираючись на великий корпус документів і опублікованих праць, автори подають історію Голокосту в контексті передвоєнного життя єврейського населення міста, розвитку воєнних дій та окупаційного режиму. Окремий розділ присвячено опору Голокосту та історіям порятунку євреїв.

Пам'ять про Голокост в Україні розглянуто в монографії Г. Касьянова ${ }^{9}$, зокрема у підрозділі «Геноциди на узбіччі» йдеться про інструменталізацію трагедії євреїв українською політичною елітою в умовах панівної ексклюзивної моделі історичної пам'яті, на яку спирається нині український національний проєкт. У нещодавно опублікованій колективній монографії «Політика і пам’ять: Дніпро - Запоріжжя - Одеса - Харків. Від 1990-х до сьогодні» ${ }^{10}$ подано досить докладну характеристику особливостей експозиції музею Голокосту в Дніпрі, а також зазначено, що у цьому місті, як і в інших регіональних столицях, ключова роль у меморіалізації Голокосту належить недержавним акторам ${ }^{11}$. Що ж до рецепції Голокосту в післявоєнний радянський і пострадянський періоди, то потрібно згадати статтю А. Портнова ${ }^{12}$, в якій він звертає увагу на подвійну меморіалізацію Голокосту, наводячи саме приклад Дніпропетровська, і на різну ідентичність загиблих, зафіксовану на меморіальних знаках. Проте цей текст пропонує радше постановку проблеми, артикуляцію феномену, а не грунтовний аналіз.

Щоб здійснити такий аналіз, потрібно, по-перше, розуміти, що конкретно відбувалося в окупованому Дніпропетровську в тих місцях, де нині встановлено пам'ятники. Тому звернемося до монографії «Голокост у Дніпропетровську» для того, щоб охарактеризувати основні місця, пов'язані зі знищенням євреїв, і події, які там відбувалися. 
${ }^{13}$ Врадій, Є. А., Рибалка, В. Г., Стрільчук, М. В., \& Шаталов, Д. В. Голокост у Дніпропетровську, 131.

14 Там само, 134.

${ }^{15}$ Нині вул. Яна Ходоровського.

${ }^{16}$ Врадій, Є. А., Рибалка, В. Г., Стрільчук, М. В., \& Шаталов,

Д. В. Голокост у Дніпропетровську, 135.

${ }^{17}$ Круглов, А., Уманский, А., \& Щупак, И. Холокост в Украине, 156.

18 Там же.

${ }^{19}$ Врадій, С. А., Рибалка, В. Г., Стрільчук, М. В.,

$\&$ Шаталов, Д. В. Голокост у

Дніпропетровську, 155.

\author{
${ }^{20}$ Там само, 156-157. \\ ${ }^{21}$ Там само, 160.
}

\footnotetext{
${ }^{22}$ Мешканці міста, які жили неподалік місць масових убивств (зокрема парку імені Писаржевського), часто згадували про людські кістки, які час від часу знаходили діти або відкопували собаки, аж до 2000-х pp.
}

\section{Місця, де було вчинено Голокост}

Дотримуючись хронологічного принципу, почнемо з місця збирання єврейського населення 13 жовтня 1941 р. на площі позаду будівлі універмагу «Люкс» (нині - Центральний універмаг) на пр. К. Маркса, $52{ }^{13}$. Людей обшукували, відбирали цінні речі, групували в колони й під конвоєм відправляли до виїзду з міста в напрямку Запорізького шосе ${ }^{14}$. У районі старого єврейського цвинтаря, біля тодішньої вул. Дарвіна ${ }^{15}$, євреїв направляли у яр, який був частиною Червоноповстанської балки на території місцевого Ботанічного саду ${ }^{16}$. Саме на цьому місці відбувався перший масовий розстріл у Дніпропетровську, який тривав два дні. Згідно $з$ німецьким звітом, 13 і 14 жовтня було вбито «приблизно 10 тисяч» євреїв командою вищого фюрера СС і поліції ${ }^{17}$. Упродовж наступного місяця там само було розстріляно ще близько тисячі євреїв ${ }^{18}$.

Надалі вже не було місць розстрілу суто для євреїв, їх страчували разом з іншими категоріями населення, переважно комуністами і партизанами. Наприкінці 1941 р. розстріли відбувалися на території протитанкового рову поблизу єврейського цвинтаря (сучасна територія парку імені Л. В. Писаржевського). За свідченнями очевидця, туди заганяли до 100 осіб щоденно, і серед них була значна кількість євреїв ${ }^{19}$.

Інша локація, де проводили розстріли, в тому числі єврейського населення, - протитанковий рів неподалік селища Верхнє (нині це ріг вулиць Янгеля та Енергетичної). Це відбувалося від грудня 1941 р. до кінця окупації. Людей привозили на машинах, оскільки тоді це місце було за чотири кілометри від міста ${ }^{20}$. Загалом за період нацистської окупації у Дніпропетровську було розстріляно від 17 до 21 тисячі євреїв ${ }^{21}$.

Отже, нагадавши, що і де відбувалося у Дніпропетровську під час Голокосту, розглянемо, як трансформувалися локації масових розстрілів у післявоєнний час.

\section{Післявоснні радянські трансформації}

Одразу після відступу німецьких військ у 1943 р. на деяких ділянках масових розстрілів провели ексгумацію тіл загиблих, насамперед на території Ботанічного саду, але в інших місцях тіла не було впорядковано належним чином, що згодом неодноразово давалося взнаки ${ }^{22}$.

У наступні десятиріччя ландшафт цих територій активно змінювався, оскільки місто стрімко забудовувалося і розвивалося. За поширеною практикою радянських часів, колишні кладовища перетворювали на парки та рекреаційні зони. Не став винятком і єврейський цвинтар, поблизу якого, як уже згадано, відбувалися розстріли євреїв та інших переслідуваних категорій населення.

На початку 1960-х рр. цей цвинтар знесли, а на його території розбили парк, названий на честь відомого радянського вченого-хіміка Л. Писаржевського. Він був похований на цьому єврейському цвинтарі, тож його могилу зберегли, встановили на ній пам'ятник і меморіальну дошку. Навколо упродовж 1960-1970-х pр. будували житлові багатоповерхівки й магазини. В іншій частині парку поблизу пішохідної алеї поставили невисоку стелу з типовим на- 
Puc. 1. Пам'ятник мирним радянським громадянам у парку імені Л. Писаржевського
Puc. 2. Пам'ятник мирним громадянам - жертвам фашизму в парку імені Ю. Гагаріна

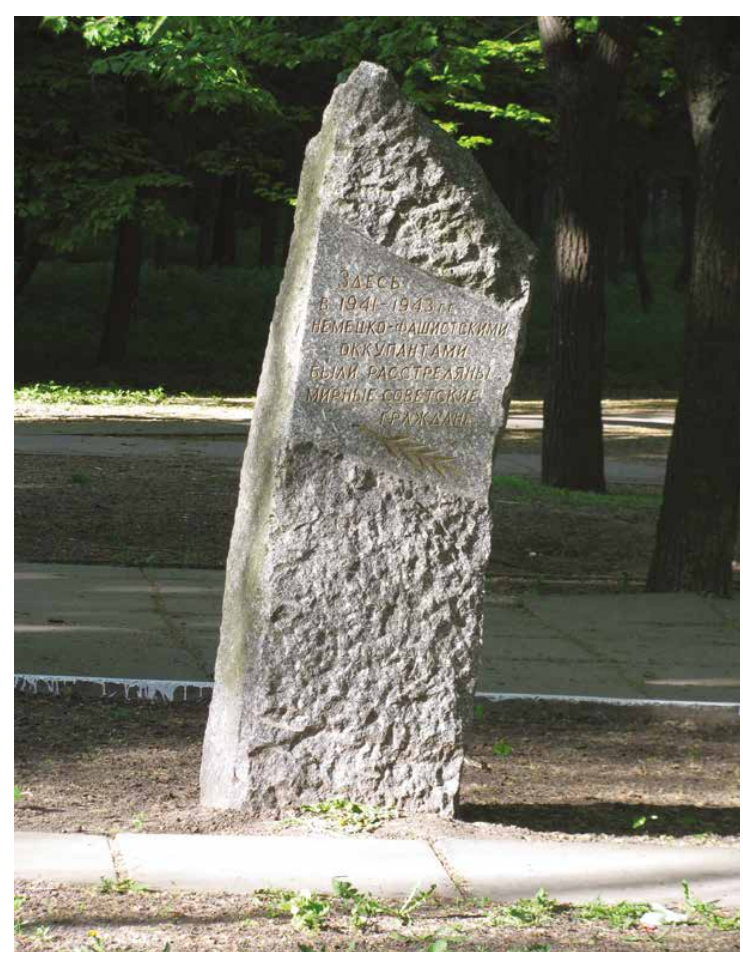

писом російською мовою: «Тут в 1941-1943 рр. німецько-фашистськими окупантами були розстріляні мирні радянські громадяни». В радянський період жодних інших дій із меморіалізації у цій локації не проводили (рис. 1).

Також зазнало суттєвих змін місце розстрілу поблизу Ботанічного саду, який функціонує дотепер. Довколишню територію досить активно забудовували, зокрема в 1970-ті було зведено перший корпус Дніпропетровського державного університету, який iз 1954 р. мав ім’я 300-річчя возз'єднання України з Росією, та інші корпуси, наукову бібліотеку, спорткомплекс, стадіон, розбито парк імені Ю. Гагаріна, в якому в 1974 р. встановлено перший стаціонарний пам'ятник. Його напис мав іще більш евфемістичний неконкретний характер - «Мирним громадянам - жертвам фашизму / жовтень 1941 р.». (рис. 2).

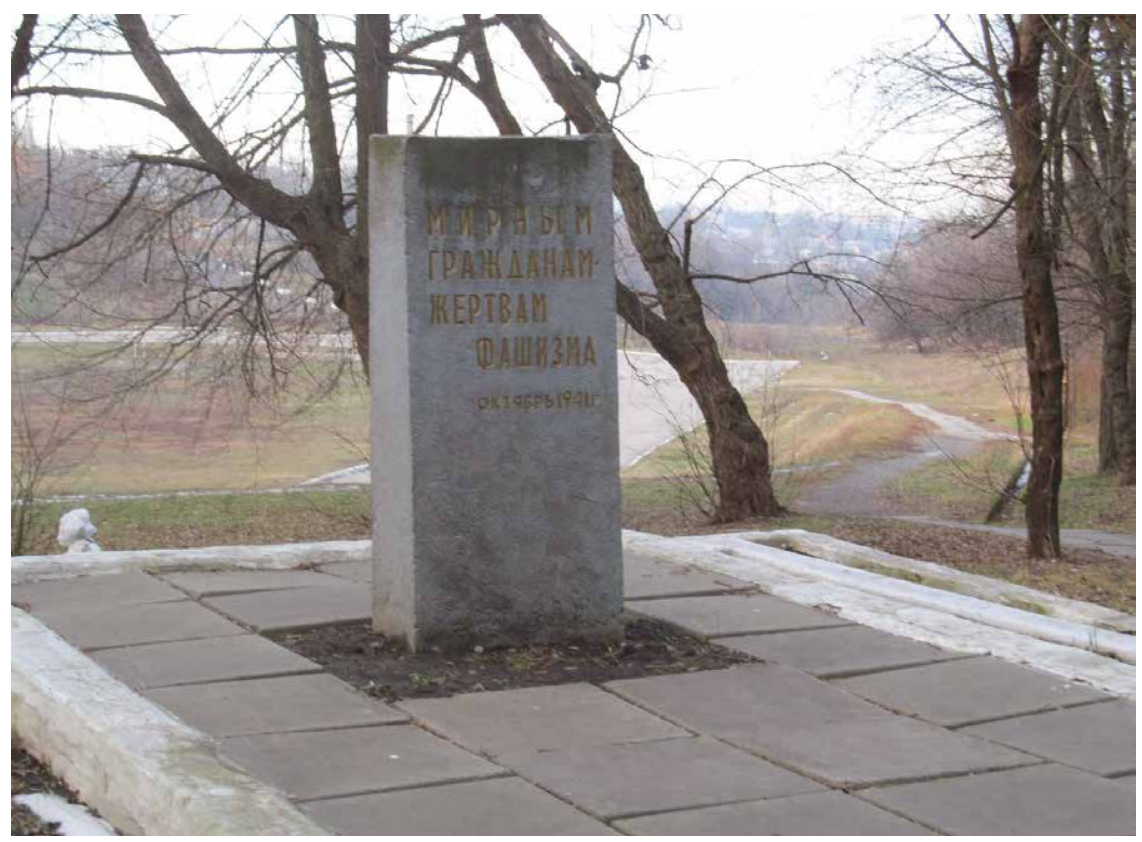


Фразеологія радянських меморіальних знаків була типовою i максимально уніфікованою, неначе пам'ятники, так само, як i будь-які інші об'єкти соціального значення (продуктові магазини, школи, пральні), не мали відбивати події, що трапилися в цьому конкретному місці, а були одиницями певної меморіальної інфраструктури, повністю позбавленими унікальних рис аж до цілковитої безликості. Різниця була тільки у ступені абстрактності. Якщо порівняти два згадані написи на пам'ятниках, установлених приблизно в один і той самий час, то можна помітити, що текст на пам'ятнику в парку імені Писаржевського хоча б має прив'язку до місця (тут), дати (1941-1943 рр.) та акції (були розстріляні), громадяни названі радянськими. На написі на стелі в парку імені Гагаріна - лише вказівка на дату, жовтень 1941 р. 3 чим може бути пов'язаний такий вибір тексту? Особливість цього місця порівняно з іншими полягає в тому, що тут розстрілювали лише євреїв, i вбивства були наймасовішими. Завданням такого напівзамовчування було формально - увіковічити пам'ять жертв, а фактично - приховати і розмити їхню долю. Все у зовнішньому вигляді пам'ятника свідчить про те, що він мав бути непомітним: колір (сірий), дизайн (прямокутник без жодних додаткових деталей), розташування (на узбіччі пішохідної алеї, яка вела 3 проспекту Гагаріна до різних будівель університету), i, звичайно, текст - настільки лаконічний і неконкретний, що красномовніше б вигляда-

${ }^{23}$ Портнов, А. (2011). О трех памятниках жертвам Холокоста. Размыциления к 9 мая. Retrieved from http://urokiistorii. $\mathrm{ru} / \mathrm{blogs} /$ andrei-portnov/1547.

${ }^{24}$ Інтерв'ю з Олександром Абрамовичем Фрідкісом, керівником справами релігійної громади м. Дніпра (2015). Аудіозапис, особистий архів автора.

\section{ла порожня плита.}

На місці розстрілів не було жодних офіційних заходів зі вшановування пам'яті загиблих аж до 1989 р. ${ }^{23}$, проте відомо, що за ініціативою невеликої групи членів єврейської громади міста там проводили таємні (неофіційні) комеморативні практики (читання пошепки єврейської молитви) саме у дати розстрілів, 13 або 14 жовтня ${ }^{24}$. Через невелику кількість учасників цих акцій місцева влада не перешкоджала їх проведенню, водночас вочевидь сприймала це місце як потенційно небезпечний єврейський символ, можливо, за аналогією з Бабиним Яром.

Отже, радянська політика пам'яті й оздоблення символічного простору передбачали одночасно і увічнення, і замовчування трагедії Голокосту, розчинення пам'яті про конкретні 11 тисяч дніпропетровських мешканців єврейського походження у багатомільйонній масі «жертв фашизму».

Що ж до місця розстрілу поблизу с. Верхнє, то у післявоєнні десятиріччя цю територію також активно забудовували, зокрема на місці протитанкового рову спорудили багатоповерховий житловий будинок (вул. Янгеля, 39), поблизу звели спортивний стадіон та іншу соціальну інфраструктуру типового житлового району радянського міста. Пам'ятник там встановили у 1980-х рр., і він принципово відрізняється від попередніх двох, передусім стилістикою. Це бронзова скульптура, що зображує чоловіка, який у піднятій високо вгору правій руці тримає птаха (рис. 3).

Підніжжя скульптури становлять кілька пірамід, які нагадують вершини гір, поміж ними прокладено доріжку зі сходами. Напис на меморіальній дошці не є оригінальним: «Місце розстрілу 20 тисяч мирних жителів у період тимчасової німецько-фашист- 
Pис. 3. Пам'ятник загиблим мирним жителям на розі вул. Янгеля та Енергетичної

${ }^{25}$ Врадій, Є. А., Рибалка, В. Г., Стрільчук, М. В., \& Шаталов, Д. В. Голокост у Дніпропетровську, 160.

${ }^{26}$ Нора, П. (2005). Всемирное торжество памяти. Журнальный зал, 2. Retrieved from http://philosophy.mipt. ru/centerphilandhist/seminars/ seminar-structure/sem110216/ nora2-arph7asf0vy.pdf.

27 Там же.

28 Там же.

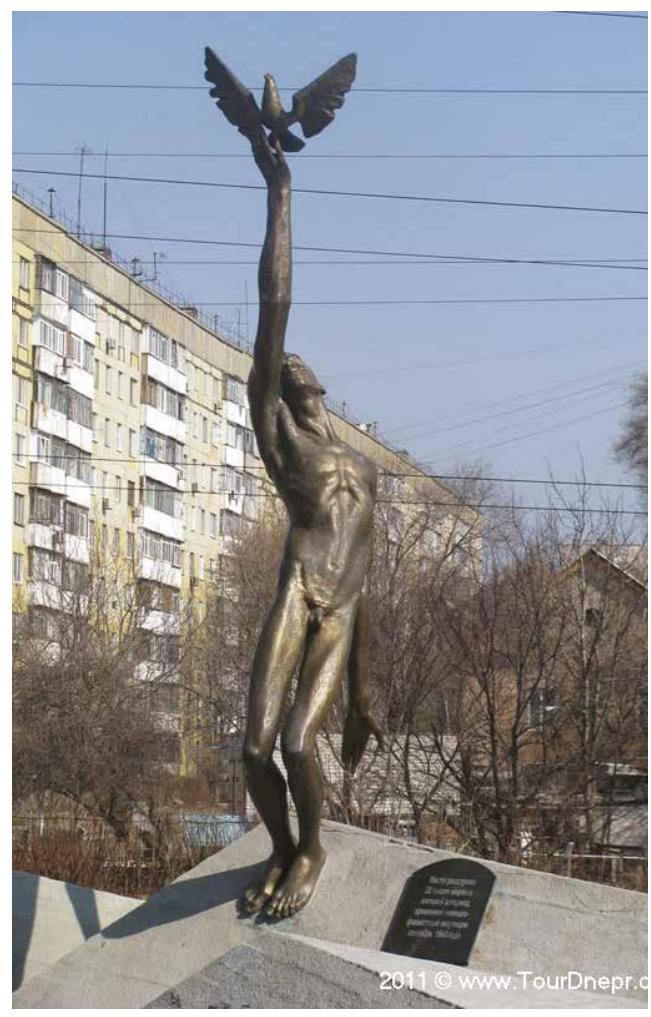

ської окупації. Вересень 1943», також російською мовою. $\mathcal{C}$ вказівка на акцію і прив'язка до місця, зазначено кількість жертв - 20 тисяч, проте їх ідентичність залишається незмінною - «мирні громадяни». Постає запитання щодо дати, зазначеної в написі, адже 3 фактологічного опису ми знаємо, що розстріли у цій локації проводили упродовж майже двох років і знищували різні категорії населення, не лише євреїв. Якщо ж припустити, що автори напису мали на меті меморіалізувати тільки тих, кого розстріляли у вересні 1943 р., то до євреїв цей

пам'ятник не може мати стосунку, оскільки, за даними німецьких реєстраційних документів, станом на 7 травня 1943 р. в місті не було зареєстровано жодного єврея ${ }^{25}$.

\section{Пострадянські трансформації}

Після розпаду Радянського Союзу, за висловом П. Нора, «настав момент “набуття пам'яті” у Східній Європі» ${ }^{26}$, який супроводжувався детабуїзацією, демократизацією історії та ідеологічною деколонізацією. Усі ці процеси передбачали виникнення внаслідок «емансипації народів, етносів, груп» ${ }^{27}$ пам'яті меншин, для яких «відвоювання свого минулого є необхідною умовою становлення власної ідентичності» ${ }^{28}$. Розглянемо, яким чином це відбилося на меморіальних практиках пострадянського Дніпропетровська.

У 2001 р. за ініціативою єврейської громади Дніпропетровська до 60-ї річниці розстрілів у парку імені Гагаріна, на відстані кілька сотень метрів від радянського пам'ятника мирним громадянам було встановлено ще один меморіальний знак. На відміну від радянського, він був пишніше оздобленим, а напис на ньому - розлогішим, зі згадкою про етнічну належність загиблих. Проєкт меморіального знаку розробив Аркадій Шміст - дніпропетровський архітектор і активний громадський діяч, учасник таємних акцій зі вшанування загиблих тут за радянських часів. Пам'ятник являє собою чорну досить високу гранітну плиту, оздоблену малюнками та єврейськими релігійними символами; по центру розміщено текст івритом і українською. Невеликий майданчик навколо пам'ятника вимощено бруківкою і оточено низькою залізною кованою огорожею, також із вкрапленням єврейських символів (зірка Давида). За єврейською релігійною традицією, біля підніжжя замість квітів лежить каміння. На пам'ятнику подано цитату з молитви 
«Отець милосердя» і такий текст: «У цій землі лежить прах 10000 мирних євреїв Дніпропетровська, жорстоко вбитих 13-14 жовтня 1941 року, і ще багатьох наших святих братів і сестер, закатованих та розстріляних фашистами (1941-1943)». Тобто вшановано пам'ять, по-перше, жертв першого і наймасовішого розстрілу (акцент на 13-14 жовтня як на знаковій даті), по-друге, тих, хто був розстріляний там упродовж років німецької окупації (рис. 4).

Puc. 4. Пам'ятник євреям, розстріляним

13-14 жовтня 1941 р. поблизу парку імені Ю. Гагаріна

${ }^{29}$ Портнов, А. О трех памятниках жертвам Холокоста.

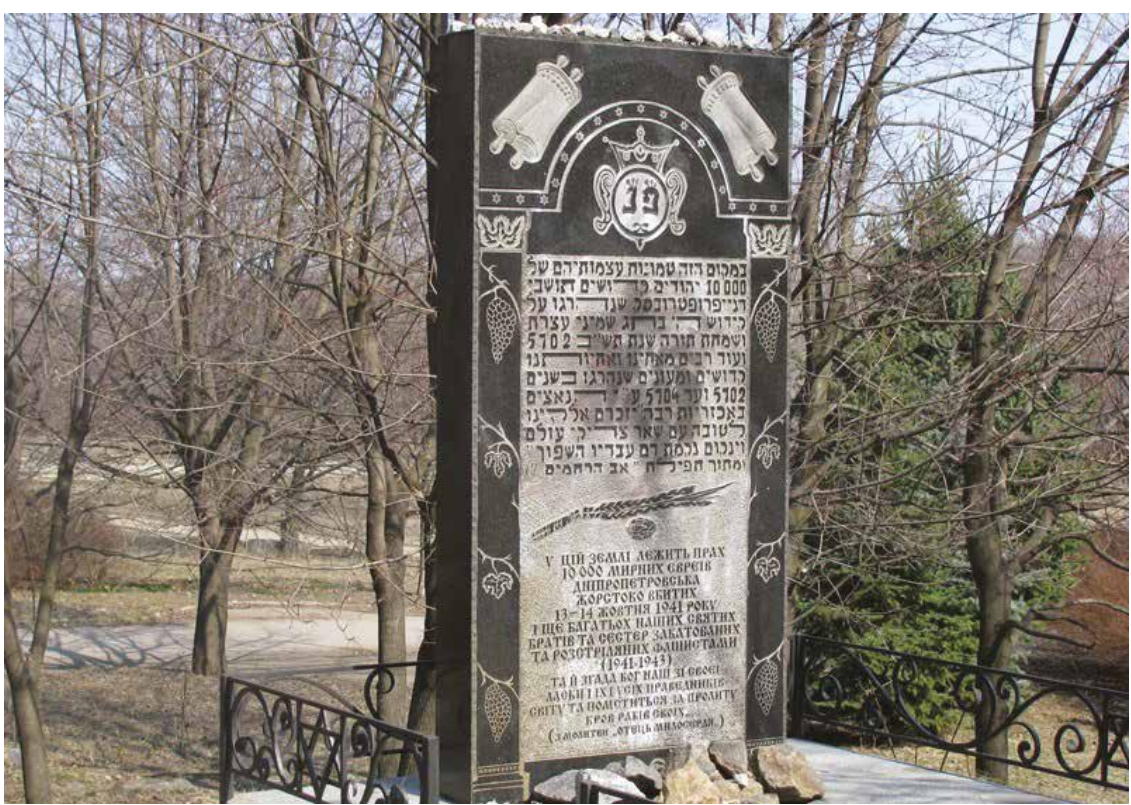

Порівнюючи два останні приклади меморіалізації Голокосту, не можна не помітити, що обидва, справді не конфліктуючи один 3 одним ${ }^{29}$, дивним чином не вписуються ані до міського простору, ані до загальноісторичного наративу міста, ніяк із ним не комунікують. Перший - через свою безликість, другий - через свою відверто єврейську ідентичність. У цих двох меморіальних практиках втілено геть різні світогляди - єврейський традиційний (релігійний) і радянський інтернаціоналістський. Із погляду представлення світоглядних позицій, зокрема уявлення про те, як необхідно вшановувати пам'ять загиблих, обидва пам'ятники цілком адекватні. А з погляду відтворення об'єктивної реальності, жоден із них на цю відповідність, на мою думку, навіть не претендує. Адже для цього треба замислитися над тим, ким насправді були євреї, які там загинули. Які форми ідентичності були їм властиві? Як і чим вони жили? Що їх об'єднувало, окрім етнічного походження? Наскільки важливими для них були національність і релігія? Звісно, в цьому випадку не може бути однозначних, простих, універсальних для всіх відповідей, однак усі ці питання мають бути об'єктом рефлексії, якщо мета встановлення меморіального знака - це не лише задовольнити потреби ініціаторів, а й адекватно представити минуле, мати відгук не лише у городян із єврейською ідентичністю, а й у інших мешканців міста.

Певний прогрес у цьому напрямі відбувся, коли в 2010 р. на стіні Центрального універмагу (нині проспект Яворницького, 52), місці, де збирали євреїв 13 жовтня 1941 р., діячі єврейської громади встановили меморіальну дошку. На ній уміщено такий текст: 
Рис. 5. Меморіальна дошка на стіні ЦУМу, звідки дніпропетровські євреї ішли на розстріл у жовтні 1941

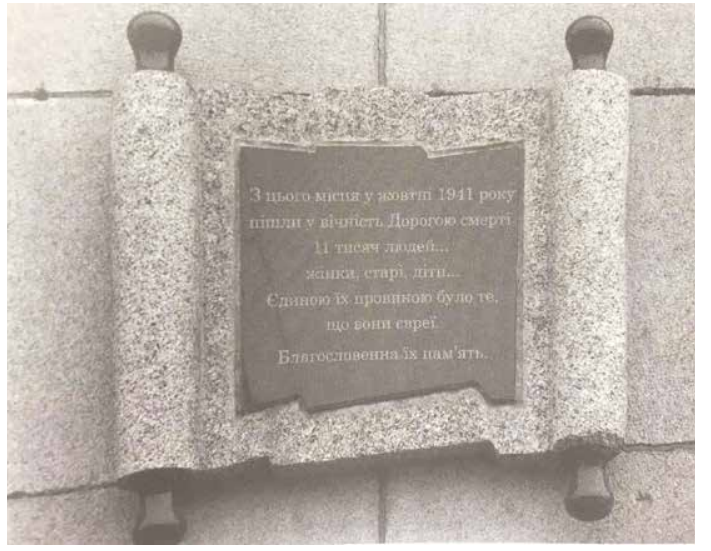

«3 цього місця у жовтні 1941 р. пішли у вічність дорогою смерті 11 тисяч людей... жінки, старі, діти... Єдиною їх провиною було те, що вони євреї. Благословенна їх пам'ять» (рис. 5).

Цей текст уже певним чином комунікує 3 міським простором, надає йому, нехай навіть у вербальній формі, певні зрозумілі образи, знаходячи для жертв додаткові ідентичності, які сприяють ототожненню їх з іншими містянами, - люди, жінки, старі, діти, згадуючи і про єврейську ідентичність, але не виносячи іiі на перший план. Отже цей меморіальний знак виконує одразу декілька функцій - інформативно-історичну (зазначаючи про подію, обставини, час, місце) і емоційну (викликає емпатію, не залишає байдужими тих, хто побачив і прочитав). Велике значення для його сприйняття має розташування на одній із будівель на центральній площі, де кожного дня проходить величезний потік людей. У такий спосіб пам'ять про Голокост у міському просторі наближається $з$ периферії до центру.

Повертаючись до меморіальних трансформацій парку ім. Л. Писаржевського в пострадянську добу, варто наголосити на його принциповій відмінності від попереднього випадку. Якщо тоді ми мали справу з двома неконфліктними об'єктами, які увіковічували одну й ту саму подію, то тут ідеться саме про конфлікт або конкуренцію пам'ятей, яка надзвичайно красномовно представлена на дуже компактному фрагменті міського простору. Отже, до пам'ятників Л. Писаржевському та розстріляним радянським громадянам, які були встановлені за радянської влади, у 2008 р. додали меморіальний хрест на вшанування пам'яті жертв Голодомору 1932-1933 рр. Ця подія відбулася у рамках загальнонаціональної компанії із меморіалізації Голодомору за ініціативою президента В. Ющенка. Хоча нашим завданням не є аналізувати цей сюжет у міському просторі, привертає увагу розташування цього пам'ятника на місці страти переважно єврейського населення в роки німецької окупації.

Постає запитання, чому міська влада поставила хреста саме на місці колишнього єврейського кладовища, власне, на одному 3 місць учинення Голокосту. Жодних письмових джерел, які б пояснювали або аргументували таку ситуацію, знайти не вдалося, однак, згідно з даними краєзнавців і розповідями старих мешканців міста, саме на цьому місці в 1932-1933 рр. ховали померлих від голоду селян, які прийшли до міста у пошуках їжі. Якщо це так, чому про це жодним чином не зазначено на пам'ятнику, щоб обгрунтувати його розташування? Щоправда, потрібно уточнити, що до 2009 р., коли в цьому парку було встановлено меморіал «Мацева» на згадку про єврейське кладовище, прямих візуальних 
Рис. 6. Напис на меморіалі «Мацева», встановленому на місці колишнього єврейського цвинтаря, де зокрема відбувалися розстріли євреїв під час німецької окупації

${ }^{30}$ Bernhard, M., \& Kubik, J., (2014). Introduction. In M. Bernhard, \& J. Kubik (Eds.), Twenty Years after Communism: The Politics of Memory and Commemoration (pp. 12-14). Oxford: Oxford University Press.

${ }^{31}$ Миллер, А. И. (2019). Рост значимости институционального фактора в политике памяти - причины и последствия. Полития, 3 (94), 90. свідчень про єврейську історію цієї місцевості ще не було. Сврейська громада не встановлювала тут окремий пам'ятник, як у парку імені Гагаріна, можливо, через те, що, за деякими свідченнями, на цьому місці розстрілювали не лише євреїв. Проте напис на табличці меморіалу містить дещо абстрактне формулювання: «Присвячується світлій пам'яті дев'яноста тисяч євреїв, що знайшли спокій у цій землі». Зважаючи на таку велику кількість, можливо, було враховано і жертв Голокосту (рис. 6).

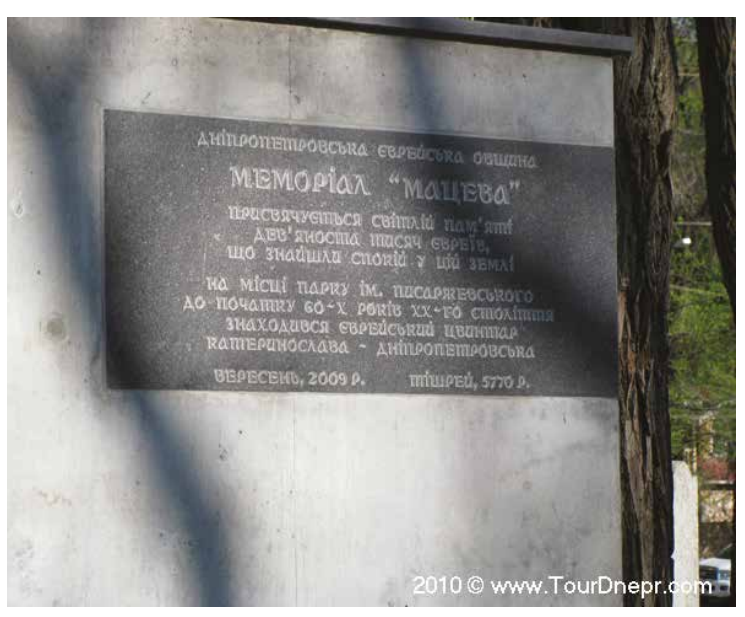

Так чи так, напевно, зважаючи на те, що у парку вже стояв пам'ятник Голодомору, єврейська громада вирішила не загострювати ситуацію і не наголошувати відкрито на Голокості. Тож зрештою ситуація не стала конфліктною через пасивність потенційних mnemonic warriors ${ }^{30}$, антагоністично налаштованих мнемонічних акторів, якими могли б виступити єврейська громада, українські активісти та радянські симпатики. Так звана діаспорна дипломатія першої групи та інертність останніх двох умовних груп засвідчила готовність ділити цей простір у тому вигляді, який він нині має.

Аналізуючи специфіку розуміння культурної пам'яті у Східній Європі, А. Міллер зазначає, що різні мнемонічні актори «нерідко релятивізують питання про історичну достовірність наративу, визнаючи право кожної національної спільноти (групи) на свій наратив» ${ }^{31}$. Власне, це і сталося у меморіальному просторі парку імені Писаржевського: усі сторони за замовчуванням визнали право кожної з них на свою ділянку цього простору.

Пов'язане з Голокостом місце на перехресті вулиць Янгеля та Енергетичної також зазнало деяких несуттєвих змін. У 2011 р. під час реконструкції стадіону, побудованого поблизу місця страт, на глибині близько пів метра від поверхні було знайдено останки 441 людського тіла. Це було ще одне свідчення того, що за радянських часів не провели ексгумацію і будівництво відбувалося у прямому значенні на кістках. 2012 року за рішенням місцевої влади тіла перепоховали поряд з уже встановленим меморіалом. Нині, вісім років по тому, на новому місці поховання стоїть тимчасова меморіальна дошка 3 таким написом (українською): «У цій могилі покояться останки 441 особи: мирних мешканців та радянських військовополонених, розстріляних у період окупації м. Дніпропетровська 1941-1943 рр.» (рис. 7).

Це єдине з трьох місць, що не містить жодного натяку на єврейську ідентичність жертв. Порівняно з написом на пам'ятнику, згадано нову категорію жертв - «радянські військовополонені», а щодо «мирних мешканців» уточнень немає. Невідомо, чи це дани- 
Рис. 7. Тимчасова меморіальна дошка, встановлена поблизу місця, де були знайдені останки людей, розстріляних під час німецької окупації, на розі вулиць Янгеля та Енергетичної

${ }^{32}$ Путеводитель по Днепропетровщине - информация о Днепропетровской области. (2011). Место расстрела немецкими оккупантами мирных граждан в Днепропетровске по улице Янгеля. Retrieved from https://tourdnepr.com/content/ view/3089/3016/.

${ }^{33}$ Відкритий. (2019). В изентре Днепра две улицы назовут в честь местных жителей, которые спасали евреев от наичистов. Retrieved from https:// opentv.media/v-tsentre-dnepradve-ulitsy-nazovut-v-chestmestnyh-zhitelej-kotorye-spasalievreev-ot-natsistov.

${ }^{34}$ Суханов, М. (2019). В Днепре назвали улицы в честь Праведников народов мира. Хадашот, апрель.

35 У лекції А. Портнова йдеться про те, що Дніпропетровськ - місто з багатьма історіями, які, однак, досі не складено в один наратив. Майже кожен знаковий сюжет у минулому цього міста має щонайменше дві версії та дві інтерпретації. Див.: Конспект лекиї А. Портнова. Дніпропетровськ. Як оповісти історію міста без історіï. Retrieved from https://www.istpravda.com. ua/articles/2012/01/26/70102/.

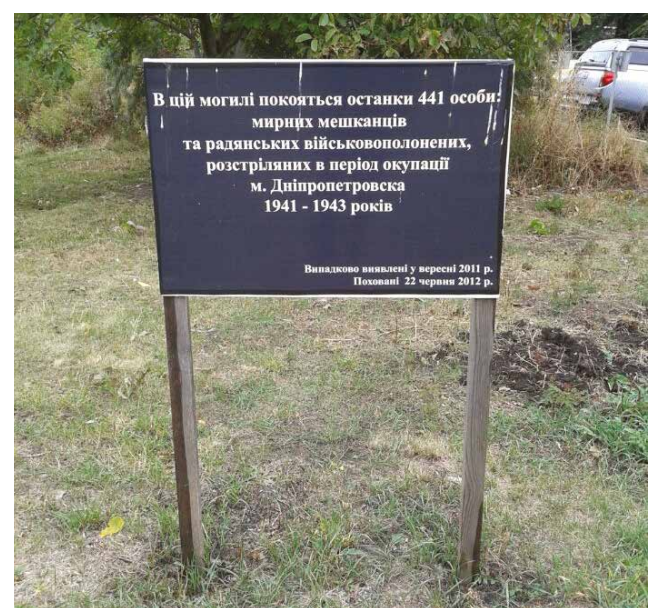

на радянській спадщині чи навмисне замовчування, але точно не незнання. Адже пошукова група, яка займалася розкопками, розподілила знайдені під час ексгумації речі між державним історичним музеєм ім. Яворницького та музеєм Голокосту ${ }^{32}$, який на той час готували до відкриття експозиції, вочевидь, маючи на увазі той факт, що частина речей могла належати розстріляним там євреям.

Ще один аспект відображення Голокосту в символічному просторі м. Дніпра, про який потрібно згадати, - топонімічний. У 2019 р. за ініціативою співробітників Українського інституту вивчення Голокосту «Ткума» було запропоновано назвати дві вулиці міста на честь Праведників народів світу ${ }^{33}$ - людей, які в часи Голокосту допомагали євреям урятуватися. Обидві вулиці розташовані в центральному районі, неподалік від тих місць, де переховували євреїв. Вулицю Дарвіна перейменували на честь Яна Ходоровського, львів'янина, який урятував 26 євреїв, улаштувавши їх за допомогою фальшивих документів на роботу до німецької фірми. Вулицю Ясну перейменували на честь подружжя Зубкових, мешканців Дніпропетровська: вони переховували, а потім удочерили єврейську дівчинку, котрій удалося врятуватися під час розстрілів в Ботанічному саду 13 жовтня 1941 p. ${ }^{34}$

Якщо спробувати виокремити наріжні риси, які сутнісно вплинули на представлення теми Голокосту в Дніпрі, то це - потужний і стійкий сентимент до радянського, терпимість і навіть схильність до еклектики, поліваріантність ${ }^{35}$ історичного минулого, його неузгодженість і як наслідок брак єдиного консенсусного наративу. Останнє зумовлює строкатість меморіального ландшафту, так би мовити, сегрегацію різних пам'ятей: навіть якщо вони зовні не конфліктують, то все одно воліють триматися на відстані. При цьому консенсус існує щодо того, як цей простір має бути поділено між українським, радянським і єврейським наративами. У випадку з Голокостом це чітко видно на прикладі трьох місць: перше (парк імені Гагаріна) - переважно єврейська зона, оскільки там убивали лише євреїв, і частково радянська; друге (парк імені Писаржевського) - три зони, а саме єврейський цвинтар, хрест (Голодомор), радянський пам'ятник (розстрілювали там переважно євреїв, однак прямої згадки про це немає); третє - на розі вулиць Янгеля і Енергетичної, суто радянська зона (однакова фразеологія як у пізньорадянському тексті, так і в пострадянському).

Однак маємо зауважити, що на тлі такої неоднорідності у Дніпрі за останні десять років з'явилася тенденція шукати спільне й ефективніше вбудовувати спадщину Голокосту до міського простору. Яскравими прикладами такого напряму є називання вулиць 
іменами Праведників народів світу, історії яких тісно пов'язані 3 містом, а також більш проникливий і об'єднувальний наратив на меморіальних знаках, зокрема на меморіальній дошці на будівлі ЦУМу. Безумовно, основним ініціатором входження і збереження пам'яті про Голокост у символічному просторі Дніпра є єврейська громада, засоби втілення цього процесу поступово змінюються. Чим більш розвиненими і впливовими стають інститути єврейської громади в місті, чим тісніше вона співпрацює і комунікує 3 різними міськими середовищами; чим більше ця громада набуває характерно міської ідентичності (усвідомлення себе не просто євреями, а дніпровськими євреями), тим ближчою стає для міста єврейська спадщина.

\section{References}

Berkhof, K. (2011). Zhnyva rozpachu. Zhyttia i smert v Ukraini pid natsystskoiu vladoiu. Kyiv: Krytyka.

Bernhard, M., \& Kubik, J. (2014). Introduction. In M. Bernhard, \& J. Kubik (Eds.), Twenty Years after Communism: The Politics of Memory and Commemoration (pp. 12-14). Oxford: Oxford University Press.

Haidai, O., et al. (2018). Polityka i pam'iat. Dnipro - Zaporizhzhia Odesa-Kharkiv. Vid 1990-kh do sohodni. Lviv: FOP Shumylovych.

Kasianov, H. V. (2018). Past Continuous: Istorychna polityka 1980-kh2000-kh: Ukraina ta susidy. Kyiv: Laurus, Antropos-Lohos-Film.

Konspekt lektsiyi A. Portnova. Dnipropetrovsk. Yak opovisty istoriyu mista bez istoriyi. Retrieved from https://www.istpravda.com.ua/articles/2012/01/26/70102/.

Kruglov, A. (2008). K voprosu o kolichestve yevreyev, unichtozhennykh eynzattsgruppamy v 1941-1943 gg. Holokost i suchasnict, 1 (3), 39-64.

Kruglov, A., Umanskiy, A., \& Shchupak, I. (2016). Kholokost v Ukraine. Reykhskomissariata "Ukraina". Gubernatorstvo "Transnistriya". Dnipro: Ukr. in-t izucheniya Kholokosta "Tkuma", Lira LTD.

Miller, A. I. (2019). Rost znachimosti Institutsional'no faktora v politike pamyati - prichiny i posledstviya. Politiya, 3 (94).

Portnov, A. (2011). O trekh pamyatnikakh zhertvam Kholokosta. Razmyshleniya $k 9$ maya. Retrieved from http://urokiistorii.ru/blogs/andrei-portnov/1547.

Portnov, A., \& Portnova, T. (2014) Stolitsa zastoya? Brezhnevskiy mif Dnepropetrovska. Neprikosnovennyy zapas, 3. Retrieved from https://magazines.gorky.media/nz/2014/5/stolicza-zastoya-brezhnevskij-mif-dnepropetrovska.html.

Portnova, T. (2017). Tema "zakrytoho mista" $v$ istoriyi radyans'koho Dnipropetrovs'ka 1950-80 rr. Retrieved from http://www.historians.in.ua/ index.php/en/doslidzhennya/2351-tetyana-portnova-tema-zakritogo-mista-v-istoriji-radyanskogo-dnipropetrovska-1950-80-kh-rokiv.

$V$ tsentre Dnepra dve ulitsy nazovut v chest' mestnykh zhiteley, Kotoryye spasali yevreyev ot natsistov. (2019). Retrieved from https://opentv.media/vtsentre-dnepra-dve-ulitsy-nazovut-v-chest-mestnyh-zhitelej-kotorye-spasalievreev-ot-natsistov.

Vradiy, Y. A., Rybalka, V. H., Stril'chuk, M. V., \& Shatalov, D. V. (2017). Holokost u Dnipropetrovsku. Dnipro: Ukrainskyi instytut vyvchennia Holokostu "Tkuma", LIRA. 


\section{Anna Medvedovska}

\section{HOLOCAUST MEMORY IN THE SYMBOLIC SPACE OF DNIPRO (DNIPROPETROVSK)}

This article aims to demonstrate the key transformations that took place at the Holocaust sites in the Dnipro (former Dnepropetrovsk) from the end of the Nazi occupation to the present day. It explores the extent to which these locations have become places of the Holocaust commemoration and describes the mechanisms and features of inclusion of such commemoration into the city's urban space. The author analyzes the main initiators and supporters of the Holocaust commemoration in order to evaluate how effectively the history of the extermination of Jews is represented in urban space of Dnipro and how much it corresponds to its contemporary image.

The article, based on existing historiography, describes events in the three main locations of the Holocaust in Dnepropetrovsk (Dnipro), where the most large-scale acts of extermination of the Jewish population took place - near the Botanical Garden (Krasnopovstanska Balka), the Jewish Cemetery (Park of Pisarzhevsky), the village of Verkhnie (the intersection of Yangel and Energetich a streets. Sufficient body of research provides a fairly reliable evidence of what took place in the aforementioned locales during the Nazi occupation. An important feature that subsequently influenced the commemoration of these places in both the Soviet and the post-Soviet periods was that in the first location, i.e. in the Krasnopovstanska Balka (ravine), those executed were exclusively Jewish, while in the other two locations, different categories of Nazi victims were executed, including a significant number of Jews.

In the 1960-1980s, a period of honoring the history of the Great Patriotic War, monuments, erected to commemorate the victims, only bore inscriptions, typical for the Soviet officialdom. These inscriptions did not mention the ethnic origin of Jewish victims, dissolving them in euphemistic formulations, such as "civilians", "Soviet citizens", etc. After the collapse of the USSR, old taboos were lifted and previously forbidden historical facts and narratives, including the identity of national groups claiming their place in historical consciousness began to take shape. This article analyzes various combinations of memorial discourses - Soviet and Jewish / Soviet and post-Soviet / Jewish, Soviet and Ukrainian - and how they relate (interact / conflict / do not communicate) in the mentioned locations.

Based on her analysis, the author concludes that the city's Jewish community was the main initiator and supporter of the preservation of the Holocaust memory, which has led to high degree of fragmentation of the commemoration of the Holocaust in Dnipro. Nevertheless, thanks to the collaboration and occasional joint activities of Jewish organizations, as well as Dnipro's public and governmental institutions, the memory of Holocaust has become gradually incorporated into the urban space, where it occupies a more prominent place.

Keywords: Holocaust memory, Holocaust representation, urban space, Holocaust location, memorial sign. 